\title{
Modeling the Impact of Climate Change on Runoff and Annual Water Balance of an Arctic Headwater Basin
}

\author{
S. POHL, ${ }^{1}$ P. MARSH ${ }^{1,2}$ and B.R. BONSAL ${ }^{1}$ \\ (Received 7 June 2006; accepted in revised form 21 December 2006)
}

\begin{abstract}
Climate change will be an important issue facing Arctic areas in the coming decades since climate models are projecting warmer and wetter conditions for many northern regions. From a hydrological perspective, critical issues include a shortened snow cover season, changes in winter snow cover properties, and changes in the timing and volume of snowmelt runoff. To assess the impacts of projected temperature and precipitation changes on the hydrology of a small Arctic headwater basin, the distributed hydrological model WATFLOOD was used in conjunction with selected Global Circulation Models (GCMs) and future climate scenarios. It was found that the hydrological model simulated basin runoff adequately either with input climate data collected in the study area or with input data from a long-term climate station located approximately $50 \mathrm{~km}$ south. WATFLOOD was then used to predict future runoff using GCM outputs for the 2040-69 and 2070-99 time periods. The results gave dates of first and peak runoff that were, on average, up to 25 days earlier than in current (1961-90) climate. In addition, future runoff and evaporation volumes increased by up to $48 \%$ as a result of projected increases in temperature and precipitation. Furthermore, a large number of simulated years showed midwinter melt periods, which will have major impacts on snowpack properties and, in turn, on human, animal, and plant life in this region.
\end{abstract}

Key words: climate change, hydrologic modeling, snowmelt, Arctic hydrology, stream record extension

RÉSUMÉ. Au cours des décennies à venir, puisque les modèles climatiques projettent des conditions plus chaudes et plus humides pour de nombreuses régions nordiques, les régions arctiques feront face à l'important enjeu du changement climatique. Du point de vue hydrologique, les enjeux critiques se traduisent par une saison de couverture de neige plus courte, par des changements du point de vue des propriétés de la couverture de neige hivernale ainsi que par des changements par rapport au moment et au volume d'écoulement de la fonte des neiges. Nous avons utilisé le modèle hydrologique distribué WATFLOOD, certains modèles de circulation globale et des scénarios climatiques futurs pour évaluer les incidences des changements projetés en matière de températures et de précipitations sur l'hydrologie d'un petit bassin d'amont de l'Arctique. Le modèle hydrologique a permis de simuler, de manière adéquate, l'écoulement du bassin soit grâce à l'introduction des données climatiques recueillies dans la région visée par l'étude, soit grâce aux données à long terme provenant d'une station climatique située à une cinquantaine de kilomètres au sud. Ensuite, WATFLOOD a permis de prédire l'écoulement futur en recourant au débit des modèles de circulation globale pour les périodes allant de 2040 à 2069 et de 2070 à 2099. D'après les résultats obtenus, les dates du premier écoulement et de l'écoulement de pointe seraient devancées de jusqu'à 25 jours par rapport au climat actuel (période de 1961 à 1990). De plus, les volumes d'écoulement et d'évaporation futurs connaissaient une augmentation atteignant jusqu'à $48 \%$ en raison des élévations prévues de températures et de précipitations. De plus, un grand nombre d'années simulées a permis de constater des périodes de fonte en plein milieu de l'hiver, ce qui aura une grande incidence sur les propriétés de la couverture de neige et, par conséquent, sur les êtres humains, les animaux et la vie végétale dans cette région.

Mots clés : changement climatique, modélisation hydrologique, fonte des neiges, hydrologie de l'Arctique, enregistrement prolongé des écoulements

Traduit pour la revue Arctic par Nicole Giguère.

\section{INTRODUCTION}

Climate observations over the last century have shown that global mean annual surface temperatures have increased by approximately 0.4 to $0.8^{\circ} \mathrm{C}$ (IPCC, 2001), while mean temperatures over southern Canada rose by an average of $0.9^{\circ} \mathrm{C}$ over the period $1900-98$. These trends are even more pronounced in the North: some parts of the Canadian Arctic (especially in the northwest) warmed by up to $3.0^{\circ} \mathrm{C}$ from 1950 to 1998 (Zhang et al., 2000). A further acceleration of these warming trends during this century is projected by all global circulation models (GCMs) (Kattsov et al., 2005). Studies have shown that the warming trend is especially noticeable during winter and spring (Bonsal and Prowse,

\footnotetext{
${ }^{1}$ National Hydrology Research Centre, 11 Innovation Boulevard, Saskatoon, Saskatchewan S7N 3H5, Canada

${ }^{2}$ Corresponding author: philip.marsh@ec.gc.ca

(C) Environment Canada
} 
2003), impacting snow accumulation, duration of snowcovered period, and snowmelt processes in Arctic regions. The snowpack has major impacts on the energy exchange between land surface and atmosphere because of its high albedo, low thermal conductivity, and the surface temperature limitation of snow-covered surfaces (Male and Granger, 1981; Gerland et al., 1999; Walker et al., 1999). A shorter snow cover period will lead to a much lower overall albedo in Arctic regions, and this process will be further enhanced by the predicted northward extension of "darker" tree and shrub vegetation, which will be far less reflective than the low tundra vegetation it is replacing. Additionally, these vegetation shifts will greatly affect snow accumulation and ablation patterns (Liston et al., 2002; Marsh et al., 2003). Another feedback mechanism involves a possible disruption of the global ocean currents and a significant rise in ocean levels due to the higher inflow of freshwater into the Arctic Ocean (Loeng et al., 2005).

The hydrology of Arctic regions is dominated by the accumulation of precipitation as snow over the winter period and the subsequent rapid release of this precipitation as meltwater during the spring. This release often leads to annual high flows and generally produces the majority of the annual flow volume in Arctic rivers and streams (McNamara et al., 1998; Marsh et al., 2002; Woo and Young, 2004). Furthermore, snowmelt runoff has important implications for lake water budgets, soil moisture conditions, active layer depth, and other permafrost characteristics (Kane et al., 1991; Hinzman et al., 1998; Nelson et al., 1998; Marsh, 1999; Liston et al., 2002). Melting snow cover also affects animal and plant life by supplying nutrients and other chemicals. In addition, human activities such as housing, transportation, and resource exploration might be affected by changing snowmelt runoff patterns (Evans et al., 1989; Walker et al., 1993, 1999; Nellemann and Thompson, 1994; Tranter and Jones, 2001).

Even though these effects are well documented, few studies have examined the impacts of projected future climate change on the hydrology of Arctic basins and runoff in Arctic rivers. This study uses GCM predictions in combination with a hydrological model to examine the first-order impacts of GCM-projected climate change on the timing and volume of runoff from a small Arctic headwater basin located in northwestern Canada. Shifts in the runoff hydrographs and peak runoff volumes will be quantified with respect to current conditions. Understanding the impacts of climatic change at the basin scale is important for a variety of studies looking at the largerscale impact of climatic change on Arctic ecosystems. Several large-scale studies have presented qualitative predictions on the impact of climate change on Arctic and global conditions (IPCC, 2001; ACIA, 2004). However, these studies give only general projections over broad regions. The current investigation focuses on a more regional scale and quantifies the changes that may be expected as long-term averages and ranges.
This study first tested the performance of a distributed hydrological model (WATFLOOD) in a small Arctic basin underlain by continuous permafrost. Model performance was then tested using climate data from Inuvik, located approximately $50 \mathrm{~km}$ to the south, as this climate station has a much longer observation record than the study area. Finally, the output from two GCMs was used to compare the basin runoff of a baseline period (1961-90) to two future 30-year periods, 2040-69 and 2070-99, hereafter referred to as "the 2050s" and "the 2080s."

\section{STUDY AREA}

The study was conducted in the research basin of Trail Valley Creek (TVC), which is located in an upland region $50 \mathrm{~km}$ north-northeast of Inuvik (NWT) at approximately $68^{\circ} 45^{\prime} \mathrm{N}, 133^{\circ} 30^{\prime} \mathrm{W}$ (Fig. 1). The area of the basin is $63 \mathrm{~km}^{2}$ and its topography consists mainly of gently rolling hills and some deeply incised river valleys, with elevations ranging from 50 to $180 \mathrm{~m}$ a.s.l. The regional climate is characterized by short summers and long cold winters, with approximately eight months of snow cover (Environment Canada, 2002). Much of the annual precipitation (67\% at Inuvik) consists of snow that accumulates over the winter and melts during spring (in May and June). Streamflow from TVC commences during snowmelt and generally ceases in late September or October.

TVC is in the continuous permafrost zone; its maximum permafrost thickness is estimated at 350 to $575 \mathrm{~m}$, and observed active layer depths reach 0.3 to $0.8 \mathrm{~m}$ (Marsh and Pomeroy, 1996). Soils are organic cryosols, consisting of an upper peat layer ranging in thickness from 0.2 to $0.5 \mathrm{~m}$ over a silty clay mineral soil (Quinton and Marsh, 1999; Petrone et al., 2000). The basin is located at the northern edge of the boreal forest-tundra ecotone, and much of its dominant upland areas are covered by open tundra. Hill slopes and valley bottoms support shrub tundra, with alder, birch, and willow shrubs 0.5 to $3 \mathrm{~m}$ high and sparse pockets of black spruce forest. Micro-meteorological observations have been conducted in the basin since 1992, while the basin runoff has been recorded since 1981. A digital elevation model (DEM) of TVC used for the modeling study was obtained by digitizing 1:50 $000 \mathrm{Na}-$ tional Topographic Survey maps (Pohl et al., 2005).

\section{METHODOLOGY}

Snowmelt runoff simulations generally consist of a snowmelt energy model that generates meltwater from a snow cover and a hydrologic routing model that moves available meltwater to the basin outlet. Certain models such as WATCLASS calculate snowmelt from the simulation of the complete snowmelt energy balance (Soulis et al., 2000). WATCLASS has been successfully applied to the study basin (Pohl et al., 2005; Davison et al., 2006). 


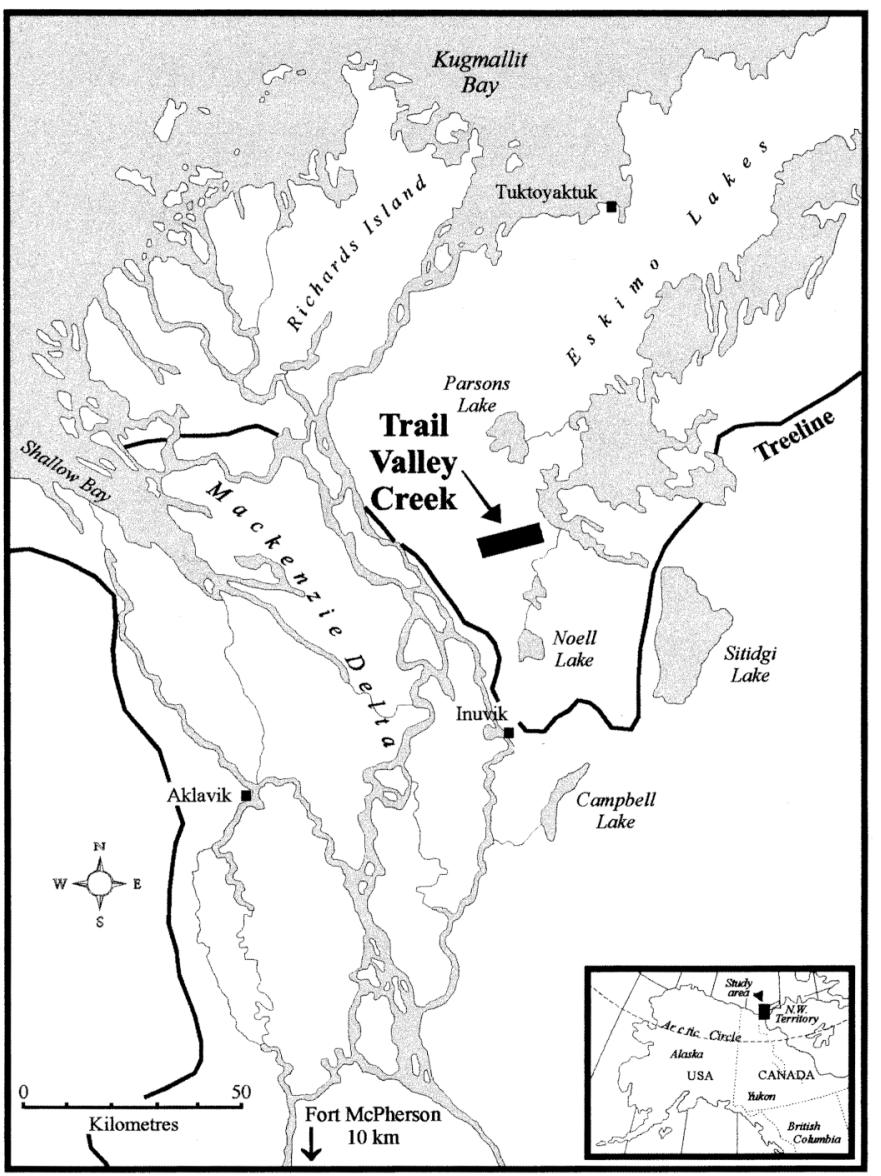

FIG. 1. Location of the study area near the Mackenzie Delta, Northwest Territories, Canada. Trail Valley Creek (TVC) is north of the treeline; however, small stands of trees are found within the TVC basin.

However, its extensive climate input demands (e.g., incoming long wave and solar radiation, wind speed, humidity, and barometric pressure) make this model unsuited for a study using GCM output, as a large portion of the data needed to characterize a 30 -year baseline climatology is not available. A number of conventional snowmelt models, including WATFLOOD, use a temperature index model to calculate melt (Hinzman and Kane, 1991; Rango, 1992; Rango and Martinec, 1995; Pietroniro et al., 1996). These less complex models are well suited for a study on the impact of future climate scenarios since the only meteorological inputs they require are air temperature and precipitation, variables for which data are readily available and deemed more reliable, both from climate stations and from GCM outputs. It was therefore decided to use the fully distributed hydrologic model WATFLOOD (Kouwen, 2001) in this study.

\section{Model Description}

To incorporate the distributed nature of a watershed and the associated state variables, WATFLOOD relies on Grouped Response Units (GRUs) (Kouwen et al., 1993). Areas within each GRU that have similar hydrological responses are grouped together, regardless of their location within the GRU, and treated separately in the runoff calculations. These similar-response areas are generally based on vegetational land cover, on the assumption that similar vegetation preferentially occurs in regions that have similar soil type and topographic conditions, and therefore, a comparable hydrologic response (Donald et al., 1995; Snelgrove, 2002). Vegetational land cover is typically determined from satellite images. The sum of runoff amounts from all similar-response areas within a GRU becomes the total runoff from the GRU available for routing. The model uses optimization procedures to estimate land cover-dependent hydrological model parameters and variables that cannot easily be derived from field observations or other sources. Observed and predicted basin outflow hydrographs are compared in the optimization procedure (Pietroniro et al., 1996).

Snowmelt is simulated using a simple temperatureindex approach. Snowmelt rates are determined from air temperature and two land cover-dependent model parameters, a melt factor and a base temperature. While this approach has been shown to be inadequate to determine small-scale snowmelt rates in open environments (Pohl et al., 2005), it does produce acceptable average snowmelt rates at the basin scale. The amount of remaining snowcovered area during the melt period is calculated from snow depletion curves that are defined individually for each land cover class. In the absence of radiation data, evaporation is determined using the Hargreaves equation (Kouwen, 2001). WATFLOOD models three forms of lateral runoff: surface runoff, following Manning's equation; interflow through the soil matrix and macro pore structure, using a simple linear reservoir approach; and base flow, from excess water in lower-zone storage (Kouwen, 2001; Pohl et al., 2005). Once the water has reached the stream network, the model routes it to the basin outlet, employing a storage routing technique (Pietroniro et al., 1996; Kouwen and Mousavi, 2002).

\section{Model Initialization}

In this study, the GRUs chosen were evenly sized 1 by $1 \mathrm{~km}$ squares covering the entire model domain. The GRUs were subdivided according to vegetational land cover, which was determined from summer Landsat ${ }^{\mathrm{TM}}$ images at a resolution of $20 \mathrm{~m}$. Four classes of land cover-open tundra, (67\% of the basin), shrub tundra (22\%), black spruce forest (2\%), and water (1\%) -were identified and validated against air photographs and extensive field observations (Pomeroy et al., 1997). Marsh and Pomeroy (1996) and Pohl et al. (2005) found that these four classes adequately described the hydrologic variability of the study basin. In the TVC basin, as in many other Arctic basins, blowing snow events cause extensive redistribution of snow, which accumulates in snowdrifts on steep slopes, at lake margins, and in the stream channels (Pomeroy et al., 1997). An additional land cover class, snowdrifts, was therefore added to address this important feature. 
$176 \cdot$ S. POHL et al.

TABLE 1. Average and range of monthly differences in observed temperature between TVC and Inuvik for nine years of data (1992-94 and 1997-2003).

\begin{tabular}{|c|c|c|c|c|c|c|c|}
\hline Month & Jan & Feb & Mar & Apr & May & Jun & \\
\hline $\begin{array}{l}\text { Average Temperature } \\
\text { Difference TVC-Inuvik }\left[{ }^{\circ} \mathrm{C}\right] \\
\text { Range in Temperature } \\
\text { Difference TVC-Inuvik }\left[{ }^{\circ} \mathrm{C}\right]\end{array}$ & $\begin{array}{c}0.4 \\
-0.9-1.7\end{array}$ & $\begin{array}{c}-0.1 \\
-0.8-0.9\end{array}$ & $\begin{array}{c}-0.7 \\
-1.3-0.0\end{array}$ & $\begin{array}{c}-2.1 \\
-2.6--1.5\end{array}$ & $\begin{array}{c}-2.6 \\
-3.1--1.9\end{array}$ & $\begin{array}{c}-2.3 \\
-3.0--1.1\end{array}$ & \\
\hline Month & Jul & Aug & Sep & Oct & Nov & Dec & Year \\
\hline $\begin{array}{l}\text { Average Temperature } \\
\text { Difference TVC-Inuvik }\left[{ }^{\circ} \mathrm{C}\right] \\
\text { Range in Temperature } \\
\text { Difference TVC-Inuvik }\left[{ }^{\circ} \mathrm{C}\right]\end{array}$ & $\begin{array}{c}-1.4 \\
-2.0--1.1\end{array}$ & $\begin{array}{c}-1.4 \\
-1.9--0.9\end{array}$ & $\begin{array}{c}-0.8 \\
-1.3--0.4\end{array}$ & $\begin{array}{c}-0.1 \\
-0.4-0.2\end{array}$ & $\begin{array}{c}0.6 \\
-0.1-0.9\end{array}$ & $\begin{array}{c}-0.4 \\
-0.7-0.7\end{array}$ & $\begin{array}{c}-1.0 \\
-1.2--0.4\end{array}$ \\
\hline
\end{tabular}

Drift areas were identified from the DEM (also at a resolution of $20 \mathrm{~m}$ ), and their locations were verified against satellite images showing late-lying snowdrifts in the spring of 1996. While drift areas cover only approximately $8 \%$ of TVC, they are crucial for the hydrology of the area, since they may hold up to $33 \%$ of the entire end-of-winter snow at TVC (Marsh and Pomeroy, 1996). Snowdrifts can persist well into the summer, augmenting the usually lower early summer runoffs from Arctic streams and rivers (Marsh and Woo, 1981; Pohl and Marsh, 2006). The resulting $20 \mathrm{~m}$ land cover maps were then aggregated to compute the fraction of each of the five land cover classes within the $1 \mathrm{~km}$ GRUs of the model. Initial snow cover conditions (snow water equivalent and snow density) were obtained from land cover-specific end-of-winter snow surveys conducted in the basin prior to melt.

An initial procedure assessed whether WATFLOOD could adequately simulate the observed runoff from TVC. For this purpose, the model was optimized and validated using meteorological data collected in the research basin during seven years (1993 and 1996-2001) for which climatological observations and end-of-winter snow surveys were available. End-of-winter snow surveys were not available for 1994 and 1995. Climatological observation stations were visited each year before snowmelt and again in early summer to collect the recorded data and check the instruments. Runoff from TVC begins during snowmelt, generally in May or early June, and lasts until September or early October. The model was run from the pre-snowmelt period until runoff ceased or until major data gaps occurred in the observed climate data.

Once it was determined that the model worked well at the basin scale with direct observational data, WATFLOOD was tested with a longer period of climatic observations from the Inuvik weather station, located approximately $50 \mathrm{~km}$ south of the study basin (Fig. 1). The Inuvik station has data from 1955 to the present, thus providing a better representation of the variability in temperature and precipitation. Daily temperature and precipitation measured at TVC were compared to data from the Inuvik station for the nine years (1992-94 and 1997-2003) in which observations were made simultaneously at both locations. The temperatures at the two locations correlated very well
$\left(\mathrm{R}^{2}=0.986\right)$. However, temperatures at Inuvik were on average $1.0^{\circ} \mathrm{C}$ warmer, with individual monthly average temperature differences as high as $2.6^{\circ} \mathrm{C}$ (Table 1). To account for these differences, the Inuvik daily temperature data were adjusted using the values in Table 1 before running the model. To avoid sudden "step-wise" temperature changes at the start or end of a month, the computed differences were assigned to the middle of each month, and adjustment factors for each day of the year were computed using linear interpolation between those midmonth dates. Precipitation did not differ greatly between the two sites and therefore was not adjusted. WATFLOOD was run with the adjusted Inuvik climate data for the 17 years (1981-94 and 1998-2001) for which TVC runoff data were available. The model was initiated on 1 October and ran until 31 September of the next year, in accordance with the hydrological year. Winter precipitation was accumulated by the model and was not updated with end-ofwinter snow survey data. Some of the accumulated snow was transferred from the open tundra land class to the snowdrift land class after a certain snow water equivalent threshold was reached. Model performance was evaluated by comparing modeled to observed outflow hydrographs for TVC.

\section{Future Climate Scenarios}

Inuvik temperature and precipitation observations from 1961 to 1990 were used as the baseline climatology. It is commonly accepted that a 30-year continuous record of recent climate containing a variety of dry, wet, cool, and warm periods defines the climate of a region and can be used to create a baseline climate (Rosenzweig and Parry, 1994; Dornes et al., 2004). Temperature data were obtained from the Adjusted Canadian Historical Climate Dataset, in which values have been adjusted to account for inhomogeneities caused by station alterations, including changes in site exposure, location, instrumentation, observing program, or a combination thereof (Vincent, 1998; Vincent and Gullett, 1999; Vincent et al., 2002). The precipitation data were taken from the Environment Canada archives.

The assessment of potential future climatic impacts on the hydrology and spring runoff requires reliable projections 
of future climate at the appropriate spatial scales. At present, climate impact researchers rely primarily on GCM output for future temperature and precipitation projections. The Canadian Climate Impacts and Scenarios (CCIS) project provides GCM-projected monthly temperature and precipitation changes over Canada for 30-year periods centered on the 2020s, 2050s, and 2080s. The output is derived from several international GCMs that the Intergovernmental Panel on Climate Change (IPCC) has recommended because they can accurately simulate globally averaged temperature and precipitation over the instrumental period of record. The projections use several future greenhouse gas and sulfate emission scenarios that are based on various assumptions regarding future economic and population growth, technological change, and energy use (Nakicenovic et al., 2000). At the time of this study, two readily available datasets from the CCIS project included GCM output for the A2 and B2 emission scenarios. These provide a broad range of future emission projections: the A2 scenario is associated with a more fossil fuelintensive world (projected mean global temperature change of 2.5 to $4.5^{\circ} \mathrm{C}$ by 2100 ), and the $\mathrm{B} 2$ with smaller greenhouse gas emissions $\left(1.5\right.$ to $3.0^{\circ} \mathrm{C}$ by 2100$)$. The $\mathrm{A} 2$ scenario projects an increase in the atmospheric $\mathrm{CO}_{2}$ concentration of about $40 \%$ for 2050 and $85 \%$ for 2080 , while the B2 scenario assumes increases of $33 \%$ for 2050 and $52 \%$ for 2080 (IPCC, 2001). An examination of future hydrology and runoff conditions in TVC was carried out using projected temperature and precipitation changes for the A2 and B2 scenarios for the available 30-year periods centered on the 2050s and 2080s.

Because the GCMs vary in their resolution, the temperature and precipitation monthly changes are first spatially interpolated to a commonly used $0.5^{\circ} \times 0.5^{\circ}$ grid, and the projections for the grid square nearest to Inuvik are used. The monthly changes are applied to the middle of each month (e.g., 15 April, 15 May, etc.) and then linearly interpolated to the daily scale. The daily changes are then applied to the observed 1961-90 time series to give future daily temperature and precipitation series for the years $2040-69$ (2050s) and 2070-99 (2080s). This is the generally recommended procedure for constructing a future climate period (IPCC, 2001). Note that it incorporates only projected changes to mean climate, and as a result, the variability in the future series remains the same as that observed from 1961 to 1990.

Because the timing of snowmelt and meltwater runoff has crucial importance for the hydrology of the study area, the analysis of the projected future climate focused on spring (April-June) temperature. However, annual precipitation was chosen to examine the impact of future climatic conditions on the annual water balance. Figure 2 compares the changes in spring temperatures and annual precipitation projected by seven GCMs (Table 2), using both the A2 and the B2 emission scenarios, for (a) the $2050 \mathrm{~s}$ and (b) the 2080s. The figures show that model projections for the 2050s are more clustered, with spring
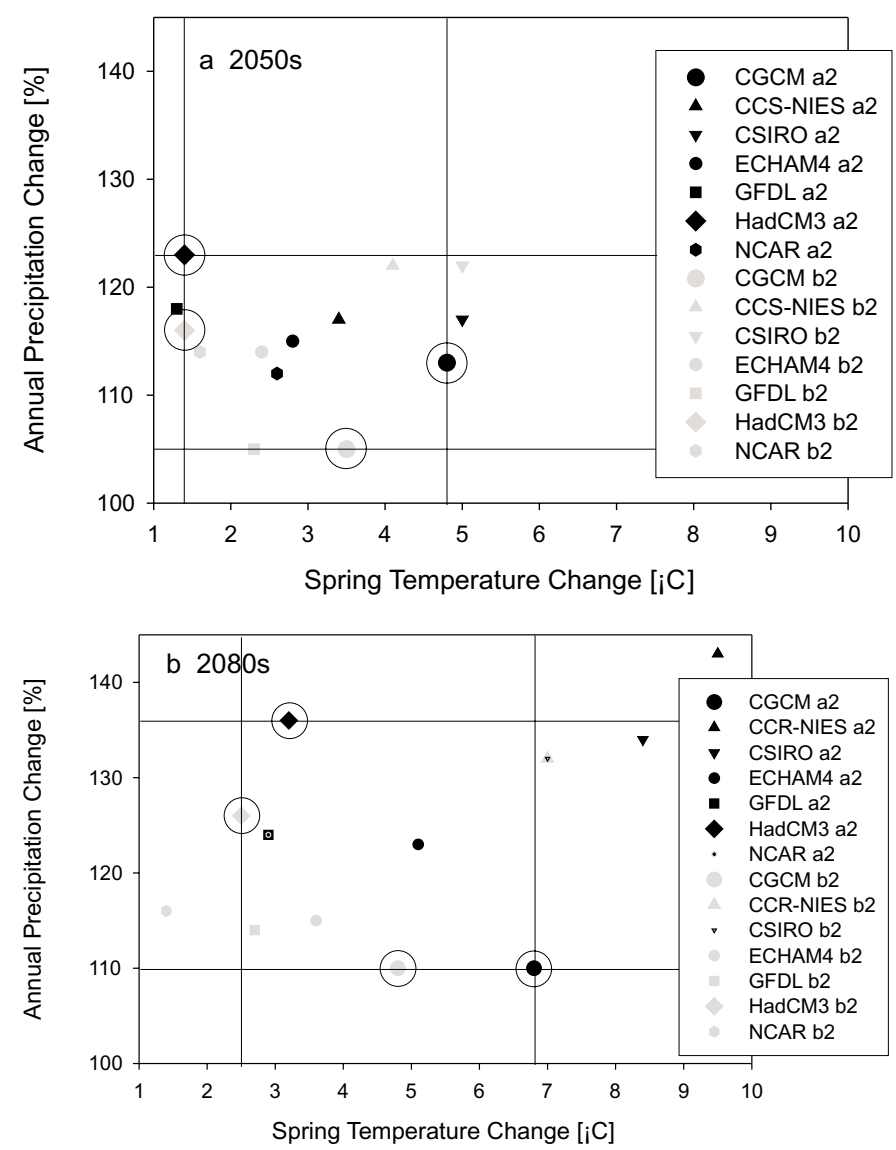

FIG. 2. Changes in spring temperatures and annual precipitation in the Inuvik region for two 30-year periods centred on (a) 2050s and (b) the 2080s, as projected by seven GCMs used in the Intergovernmental Panel on Climate Change (IPCC) report published in 2001. The circled climate projections indicate the model scenarios used in the present study.

temperature increases between 1.3 and $5.0^{\circ} \mathrm{C}$ and annual precipitation increases ranging from $5 \%$ to $23 \%$. The projections for the 2080s have a larger spread with spring temperature warming ranging from 1.4 to $9.5^{\circ} \mathrm{C}$ and annual precipitation increases from $10 \%$ to $43 \%$.

WATFLOOD was run with the data from four future climate projections, HadCM3 A2 and B2 and CGCM2 A2 and $\mathrm{B} 2$. These four scenarios cover a wide range of climate projections, especially for the 2050s (Fig. 2a). The HadCM3 $\mathrm{A} 2$ and $\mathrm{B} 2$ represent the cool, wet case of low temperature changes $\left(1.4^{\circ} \mathrm{C}, 1.4^{\circ} \mathrm{C}\right)$ but higher precipitation increases $(23 \%, 16 \%)$, while the CGCM2 A2 and B2 projections are typical for warm, dry projections with higher temperature increases $\left(4.8^{\circ} \mathrm{C}, 3.5^{\circ} \mathrm{C}\right)$ and low to moderate precipitation changes $(13 \%, 5 \%)$. Since all the other variables in WATFLOOD remain constant, these four projections should represent a range of changes in hydrologic response to projected future climate changes. For the 2080s, even though the spread in the model projections is much larger (Fig. 2b), the four selected model projections cover a large part of the projected conditions. The HadCM3 A2 and $\mathrm{B} 2$ again represent a minor warming with higher precipitation increases $\left(3.2^{\circ} \mathrm{C}, 2.5^{\circ} \mathrm{C}, 36 \%, 26 \%\right)$, while the $\mathrm{CGCM} 2 \mathrm{~A} 2$ and $\mathrm{B} 2$ show a greater temperature change, 
TABLE 2. GCMs considered in the study. CGCM2 and HadCM3 were used for detailed comparison of future changes in hydrology at TVC.

\begin{tabular}{|c|c|}
\hline GCM Organization & Version \\
\hline Canadian Centre for Climate Modelling and Analysis & $\mathrm{CGCM} 2$ \\
\hline Japanese National Centre for Atmospheric Research & CCR-NIES \\
\hline \multicolumn{2}{|l|}{ Australian Commonwealth Scientific } \\
\hline and Industrial Research Organization & CSIRO \\
\hline German Climate Research Centre & ECHAM4 \\
\hline USA Geophysical Fluid Dynamics Laboratory & GFDL \\
\hline Hadley Centre for Climate Prediction and Research & HadCM3 \\
\hline USA National Centre for Atmospheric Research & NCAR \\
\hline
\end{tabular}

but a smaller precipitation increase $\left(6.8^{\circ} \mathrm{C}, 4.8^{\circ} \mathrm{C}, 10 \%\right.$, $11 \%)$. Another reason for using these two models for the present study was the intra-annual variability in the models' predictions. Figure 3 shows the projected monthly changes in temperature and precipitation from the four climate projections for (a) the 2050s and (b) the 2080s. It shows that within the year, the CGCM2 model predicts maximum warming to occur in late winter and especially during the crucial spring period, while the HadCM3 model projections show the least amount of warming during the spring.

\section{RESULTS}

\section{Model Evaluation}

WATFLOOD was implemented for the study area and run for seven years (1993 and 1996-2001) using observed TVC temperature and precipitation data. For each year, the model was initiated before snowmelt began (15 May for 1993, 1996, 2000, and 2001; 1 May for 1997; and 20 April for 1998 and 1999). The years 1993 and 1997 were used for model calibration and the other five years for model validation. The two calibration years were chosen to cover a range of different melt conditions. In 1993 the snow melted fairly rapidly, resulting in a well-defined peak, while in 1997 a more protracted melt produced a broader runoff peak. The calibration procedure was conducted in two steps. First, the model variables used for the snowmelt calculation (base temperatures and melt factors for the individual land classes) were calibrated, using only the spring runoff hydrographs from 1993 and 1997. Second, the other model variables describing soil and river channel properties were calibrated, using the entire hydrographs for the two years. Comparisons of observed and simulated runoff are shown in Figure 4, while Table 3 provides relevant statistics, including the correlation factor $\mathrm{R}^{2}$ and the Nash-Sutcliffe model efficiency coefficient (NSC) for the model simulations. The NSC has values between - $\infty$ and 1 and represents the proportion of initial variance explained by the model with values equal to 1 indicating a perfect fit between observed and predicted data.
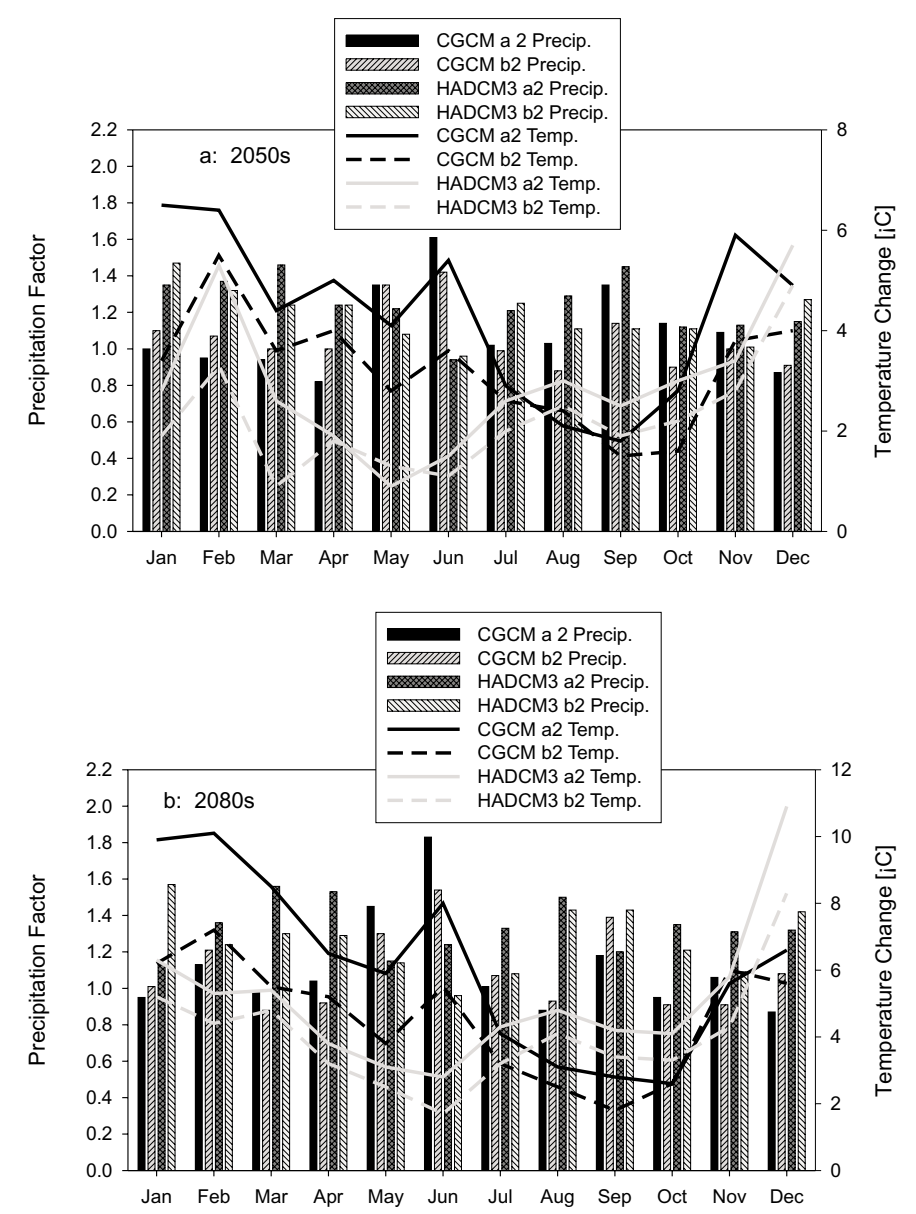

FIG. 3. Monthly changes in temperatures and precipitation (as a factor of current versus projected future monthly precipitation) projected by the four model scenarios used in the study for the Inuvik region in (a) the 2050s and (b) the $2080 \mathrm{~s}$

Overall, WATFLOOD was able to predict the timing of spring runoff initiation and peak meltwater runoff accurately, with a maximum difference of two days. The quality of the model predictions seems to be unaffected by the timing of the melt; it simulated years with an early meltwater runoff (i.e., 1998, when peak runoff was observed on DOY 138, or 18 May) equally as well as years with a late snowmelt (such as 2001, when peak runoff occurred on DOY 162, or 11 June). The model did exhibit a bias towards overestimating runoff volume, which lowered the $\mathrm{R}^{2}$ values, and particularly, the NSC values. Other studies (Pietroniro et al., 1996) have noted a similar bias in WATFLOOD for northern regions. A likely reason for this bias could be the land cover-based end-of-winter snow surveys for open tundra, which might under-represent the areas of wind-eroded snow cover identified in earlier studies (Essery et al., 1999; Pohl and Marsh, 2006; Pohl et al., 2006). Additionally, snowdrift areas are defined from the DEM as slopes of more than $9^{\circ}$, and this approach might overestimate the actual drift areas. In reality, these slopes are areas where snowdrifts might form. However, it is doubtful that snowdrifts similar to the one sampled in the drift snow survey actually form on all of these slopes. 
TABLE 3. Model statistics for simulations using TVC climate data. Note that 1993 and 1997 were used in model calibration (DOY 146 $=26$ May, DOY $154=3$ June)

\begin{tabular}{|c|c|c|c|c|c|c|c|c|c|}
\hline \multirow[b]{2}{*}{ Year } & \multirow{2}{*}{$\begin{array}{c}\text { Volume } \\
\text { Simulated vs. } \\
\text { Observed Ratio }\end{array}$} & \multirow[b]{2}{*}{$\mathrm{R}^{2}$} & \multirow[b]{2}{*}{ NSC } & \multicolumn{2}{|c|}{ First Runoff } & \multicolumn{2}{|c|}{ Peak Runoff } & \multicolumn{2}{|c|}{ Peak Daily Runoff } \\
\hline & & & & Observed DOY & Simulated DOY & Observed DOY & $\overline{\text { Simulated DOY }}$ & Observed $\mathrm{m}^{3} / \mathrm{s}$ & Simulated $\mathrm{m}^{3} / \mathrm{s}$ \\
\hline 1993 & 1.24 & 0.91 & 0.87 & 146 & 146 & 154 & 153 & 6.5 & 7.2 \\
\hline 1996 & 0.91 & 0.68 & 0.6 & 146 & 145 & 150 & 152 & 6.4 & 4.1 \\
\hline 1997 & 1.53 & 0.61 & 0.27 & 141 & 140 & 158 & 158 & 5.8 & 4.2 \\
\hline 1998 & 1.07 & 0.54 & 0.3 & 132 & 131 & 139 & 138 & 6.1 & 7.5 \\
\hline 1999 & 1.52 & 0.84 & 0.39 & 145 & 144 & 155 & 155 & 4.4 & 7.8 \\
\hline 2000 & 1.26 & 0.88 & 0.86 & 157 & 157 & 161 & 160 & 10 & 11.2 \\
\hline 2001 & 1.24 & 0.93 & 0.91 & 158 & 156 & 162 & 163 & 9.2 & 8.7 \\
\hline AVG & 1.25 & 0.77 & 0.61 & 146.4 & 145.6 & 154.1 & 154.1 & 6.9 & 7.2 \\
\hline $\begin{array}{l}\text { AVG } \\
\text { (with }\end{array}$ & $\begin{array}{c}1.20 \\
\text { out } 1993,1997)\end{array}$ & 0.77 & 0.60 & 147.6 & 146.6 & 153.4 & 153.6 & 7.2 & 7.8 \\
\hline
\end{tabular}

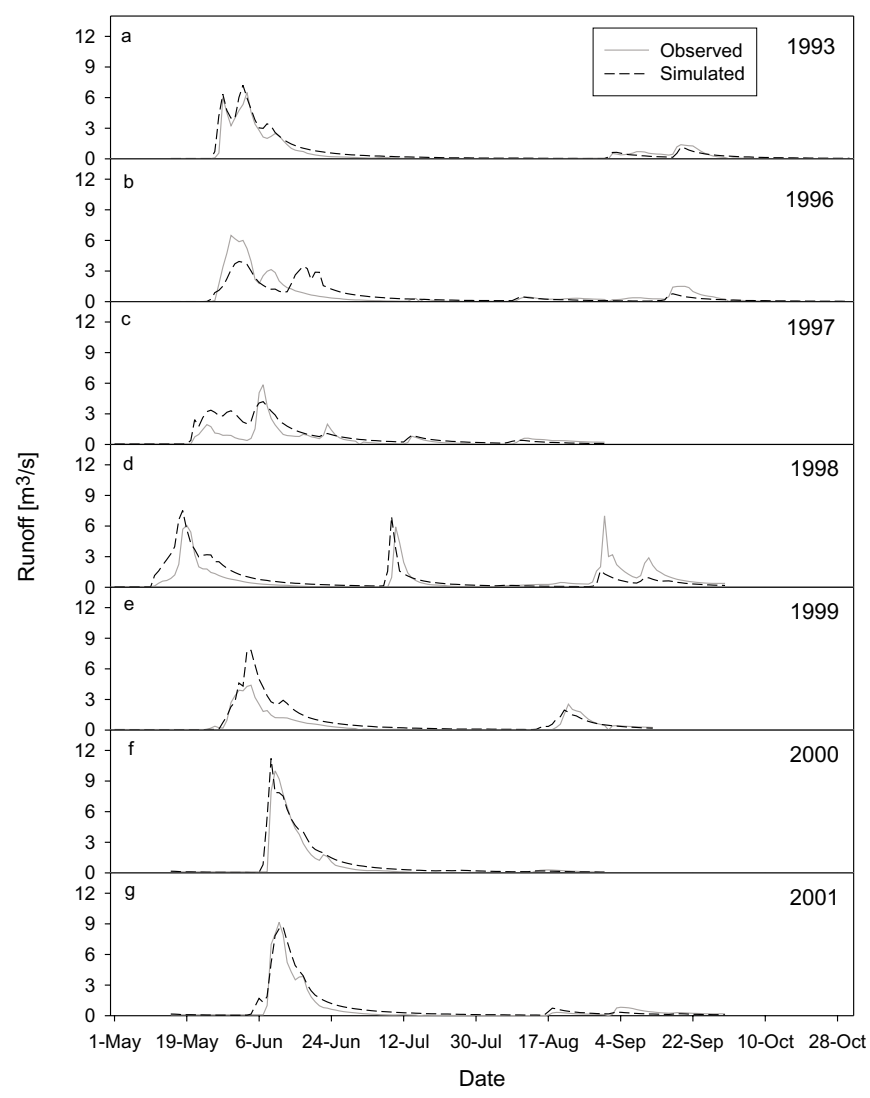

FIG. 4. Observed versus simulated hydrographs for Trail Valley Creek for seven years of modeling. Note that 1993 and 1997 were used as calibration years.

As a result, the snow cover initialization for snow drifts probably overestimates the amount of snow deposited in drift areas. The overestimated flow volumes also cause the simulated peak flows to be, on average, slightly higher than the observed values.

Most of the rain-induced flow peaks in TVC are caused by convective precipitation events in late summer, and the model generally underestimates the volume and peak flow of these events (see Fig. 4a, b, d, and e). Thus, the study area likely retains more water from the snowmelt in storage than is predicted by WATFLOOD, which explains the more pronounced reaction of the area to late summer rainfalls compared to the model predictions. Nevertheless, the comparison shows that, for the most part, WATFLOOD is able to reproduce the observed hydrographs under a wide variety of end-of-winter snow covers and melt conditions. Furthermore, model statistics for all the model periods are not considerably different from those for the validation years only (Table 3 ).

Results for simulated versus observed runoff in TVC using the adjusted Inuvik climate data are shown in Table 4. As in the previous runs using the TVC climate data, the model predicted the melt timing reasonably. On average, the first day of runoff was predicted to be four days earlier than observed. However, it should be noted that predictions were early by more than 15 days in three of the years. For the other 14 years, the average difference was only one day. The three outliers likely occurred because in those years there was a greater difference in spring air temperatures between TVC and Inuvik. As a result, the averaged air temperature adjustments made by the model were too small, and the predicted dates of runoff initiation in those years were much too early compared to the actual dates. This theory was tested for 1998, the only year with a considerably earlier predicted day of first runoff for which temperature data for TVC were available. The comparison showed that the differences in early spring (April) temperatures between Inuvik and TVC were on average $0.6^{\circ} \mathrm{C}$ greater than the monthly averages used for the temperature adjustments, meaning that the actual daily TVC temperatures throughout April were on average $0.6^{\circ} \mathrm{C}$ cooler than the adjusted Inuvik temperature used in the model simulations. This difference in temperatures explains the earlier predicted snowmelt.

The timing of peak runoff was better simulated: the predicted date was only 0.6 days earlier on average, with a maximum error of four days. This is especially important, as the timing of the highest runoff is crucial for a wide variety of human and natural activities. The 17 years used in this model validation cover a wide range of melt timing. Observed days of peak runoff range from DOY 138 (18 May) in 1991 and 1998 to DOY 163 (12 June) in 2001. The 
$180 \cdot$ S. POHL et al.

TABLE 4. Model statistics for simulations using Inuvik climate data.

\begin{tabular}{|c|c|c|c|c|c|c|c|c|}
\hline Year & $\begin{array}{c}\text { Volume } \\
\text { Simulated vs. } \\
\text { Observed Ratio } \\
\end{array}$ & $\mathrm{R}^{2}$ & NSC & $\begin{array}{c}\text { First Runoff } \\
\text { Simulated - } \\
\text { Observed Days }\end{array}$ & $\begin{array}{c}\text { Peak Runoff } \\
\text { Simulated - } \\
\text { Observed Days }\end{array}$ & $\begin{array}{c}\text { Peak Runoff } \\
\text { Simulated vs. } \\
\text { Observed Ratio }\end{array}$ & $\begin{array}{c}\text { Peak Daily Runoff } \\
\text { Observed m } 3 / \mathrm{s}\end{array}$ & $\begin{array}{c}\text { Peak Daily Runoff } \\
\text { Simulated } \mathrm{m}^{3} / \mathrm{s}\end{array}$ \\
\hline 1981 & 0.72 & 0.21 & 0.09 & -17 & -4 & 0.99 & 7.2 & 7.1 \\
\hline 1982 & 1.10 & 0.85 & 0.84 & 1 & -1 & 1.25 & 8.1 & 10.1 \\
\hline 1983 & 1.31 & 0.77 & 0.49 & 0 & -1 & 1.18 & 8.0 & 9.4 \\
\hline 1985 & 1.06 & 0.73 & 0.73 & 0 & 2 & 1.06 & 7.0 & 7.4 \\
\hline 1986 & 1.50 & 0.87 & 0.85 & 0 & 1 & 0.93 & 8.7 & 8.1 \\
\hline 1987 & 1.70 & 0.80 & 0.32 & 0 & 1 & 1.49 & 7.3 & 10.9 \\
\hline 1988 & 1.52 & 0.35 & -0.50 & -15 & -3 & 2.06 & 5.3 & 10.9 \\
\hline 1989 & 1.38 & 0.82 & 0.58 & 0 & -1 & 1.56 & 8.0 & 12.5 \\
\hline 1990 & 1.97 & 0.82 & -0.19 & -1 & -2 & 1.73 & 4.8 & 8.3 \\
\hline 1991 & 1.97 & 0.53 & -0.75 & -7 & -1 & 2.34 & 4.1 & 9.6 \\
\hline 1992 & 1.83 & 0.70 & 0.03 & 2 & 1 & 1.62 & 6.0 & 9.7 \\
\hline 1993 & 1.27 & 0.67 & 0.56 & -3 & 1 & 1.47 & 6.5 & 9.6 \\
\hline 1994 & 1.74 & 0.82 & 0.47 & 0 & -1 & 0.97 & 8.7 & 8.4 \\
\hline 1998 & 0.95 & 0.31 & 0.03 & -20 & 1 & 1.28 & 6.1 & 7.8 \\
\hline 1999 & 1.04 & 0.77 & 0.72 & -6 & -4 & 1.41 & 4.4 & 6.2 \\
\hline 2000 & 1.17 & 0.91 & 0.91 & -1 & 0 & 1.16 & 10.0 & 11.6 \\
\hline 2001 & 0.93 & 0.82 & 0.82 & 0 & 1 & 0.97 & 9.2 & 8.9 \\
\hline AVG & 1.36 & 0.69 & 0.35 & -3.9 & -0.6 & 1.31 & 7.0 & 9.2 \\
\hline
\end{tabular}

model performed equally well for early versus late snowmelts, indicating that it is well suited for studying the impact of changing climatic conditions.

The model's overprediction of the overall flow volumes increased to an average of $36 \%$ compared to $20 \%$ for the model runs using TVC data (see Table 3 ). As a result, the peak runoff volumes were also overpredicted by an average of $31 \%$. Blowing snow processes in the study basin are likely the reason for both overpredictions. During winter, open Arctic basins like TVC are very prone to blowing snow events not only because of frequent high-speed winds, but also because they lack the vegetation and meltfreeze cycles that stabilize the snow cover (Pomeroy et al., 1997; Essery et al., 1999). Studies have shown that in addition to redistribution, blowing snow events in Arctic basins also cause a significant sublimation loss, on average $9-22 \%$ of annual snowfall (Pomeroy et al., 1997; Liston et al., 2002). This sublimation loss is not accounted for in the Inuvik precipitation data used to run the model; therefore, it is not considered in our approach to modeling snow accumulation, which uses only the Inuvik precipitation data.

\section{Future Climate}

To establish a baseline runoff, WATFLOOD was run for TVC with Inuvik climate data for the years 1961 to 1990. Subsequently, the model was run with climate data from the eight future climate scenarios (CGCM2 A2 and B2, HadCM3 A2 and B2 for the 2050s and 2080s) as discussed above under Future Climate Scenarios. For the period 1961-90, the average day of first runoff was JD 139 (19 May), whereas that of peak runoff was JD 153 (2 June). Table 5 shows the differences in 30-year averages for first day of runoff, day of peak runoff, and peak runoff volume between the baseline model run and those using the future climate scenarios for the 2050s and 2080s. For the 2050s, the warm, dry CGCM2 A2 scenario predicts the largest changes in runoff timing: the average day of first runoff is projected to occur 17 days earlier, and average peak runoff, 14 days earlier.

Figure 5a shows that using the warm CGCM2 A2 projection, all simulated days of peak runoff for the 2050s occur earlier than the 1961-90 normal. For individual model years, the maximum difference in date of first runoff is 37 days, while the maximum peak runoff difference is 36 days. The cooler HadCM3 B2 scenario projects the least amount of change for this period, shifting the average date of first runoff by six days and that of peak runoff by three days (Table 5). Figure 5a shows that using the HadCM3 B2 scenario, peak runoff occurs earlier than the normal in 21 out of the 30 years. Maximum differences are 26 days for first runoff and 27 days for peak runoff. The shift in runoff patterns is further illustrated in Figure 6a, which shows the number of occurrences of simulated peak runoff dates within 10-day intervals for current conditions and the 2050s. The figure shows that for the 2050s, the majority of simulated runoffs occur at times that are still within the currently observed range.

As expected, changes are more pronounced for the 2080s simulations. Using the CGCM2 A2 projection, the average days of first and peak runoff are predicted to shift by 25 and 22 days, with individual years differing from the normal by as much as 63 days (first runoff) and 46 days (peak runoff). The model runs using the HadCM3 B2 scenario show average shifts of 11 days for first runoff and 6 days for peak runoff, with maximum individual differences of 34 and 29 days. Figure $5 \mathrm{~b}$ shows that peak runoff occurred earlier than the 1961-90 normal in all the years using the CGCM2 A2 projection, and in 23 of 30 years using the HadCM3 B2 scenario. Figure 6b illustrates the more substantial shift in peak runoff dates for the 2080s: 
TABLE 5. Statistics for comparison of baseline climatology to future climate scenarios.

\begin{tabular}{|c|c|c|c|c|c|c|}
\hline \multirow[b]{2}{*}{ Model Scenario } & \multicolumn{2}{|c|}{$\begin{array}{c}\text { First Day of Runoff } \\
\text { Mean Projected Change (days) }\end{array}$} & \multicolumn{2}{|c|}{$\begin{array}{c}\text { Day of Peak Runoff } \\
\text { Mean Projected Change (days) }\end{array}$} & \multicolumn{2}{|c|}{$\begin{array}{c}\text { Peak Daily Runoff } \\
\text { Mean Projected Change (\%) }\end{array}$} \\
\hline & $2050 \mathrm{~s}$ & $2080 \mathrm{~s}$ & $2050 \mathrm{~s}$ & $2080 \mathrm{~s}$ & $2050 \mathrm{~s}$ & $2080 \mathrm{~s}$ \\
\hline CGCM2 B2 & -14 & -19 & -10 & -14 & 92 & 80 \\
\hline HadCM3 A2 & -6 & -15 & -3 & -8 & 109 & 105 \\
\hline HadCM3 B2 & -6 & -11 & -3 & -6 & 107 & 106 \\
\hline
\end{tabular}
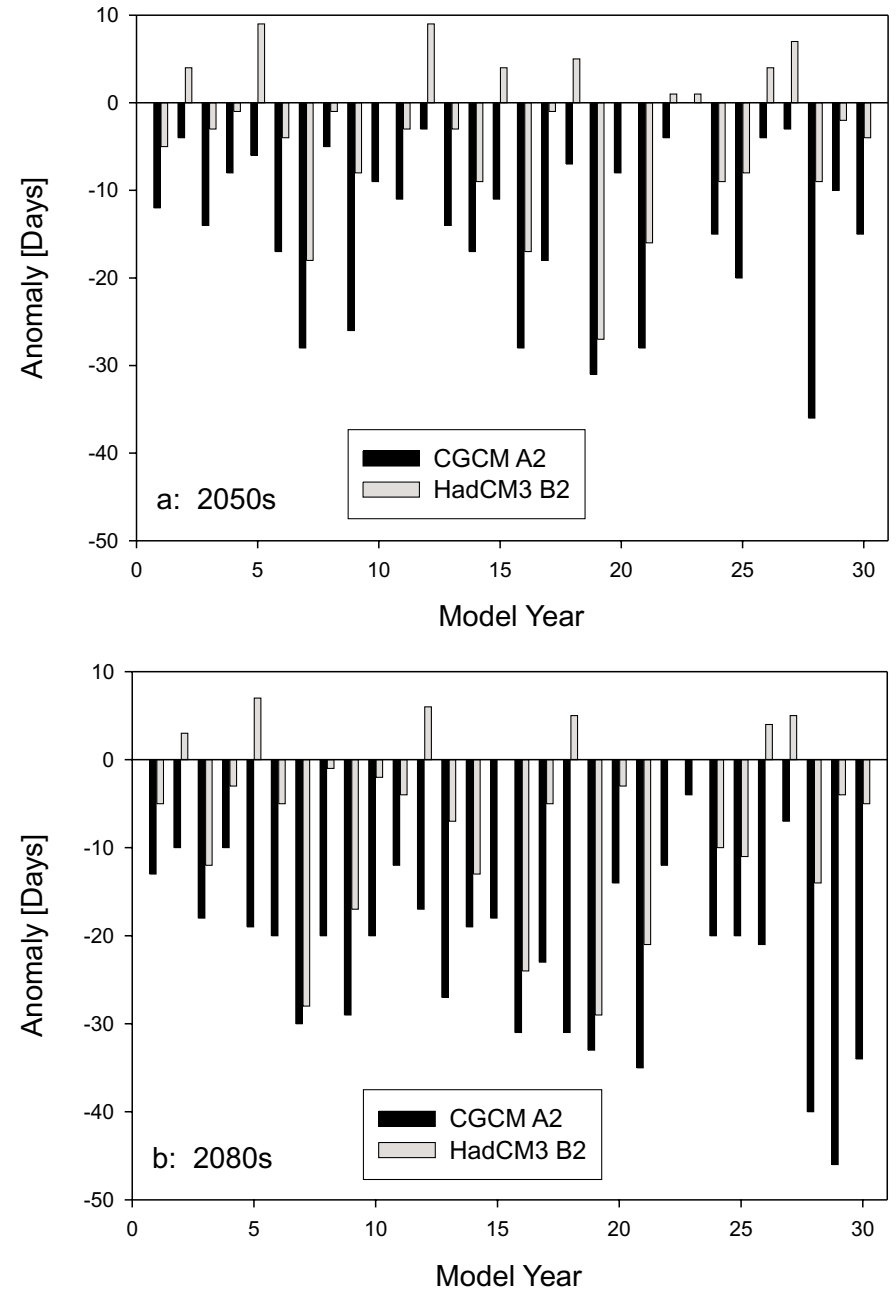

FIG. 5. Yearly comparison showing differences in simulated date of peak runoff compared to the 1961-90 normal (DOY 153, 3 June, shown by horizontal line) using two future climate scenarios for (a) the 2050s and (b) the 2080s.

for the warm CGCM2 A2 scenario, most predicted dates of peak flow occur at times rarely simulated for the current baseline climatology.

The simulated changes in peak runoff amount differ considerably between the two GCMs used. The use of the warm, dry CGCM2 scenarios leads to a reduced peak runoff value and a reduced runoff coefficient (the fraction of precipitation water that leaves the basin as runoff) compared to the baseline runs (Table 6). On the other hand the cool, wet HadCM3 scenarios produce hydrographs that show a slight increase in peak runoff volumes and in the runoff coefficient. The maximum absolute increase in peak runoff volume for individual years was projected for the HadCM3 A2 2080s scenario, with a difference of $5.0 \mathrm{~m}^{3} / \mathrm{s}\left(19.7 \mathrm{~m}^{3} / \mathrm{s}\right.$ as compared to $\left.14.7 \mathrm{~m}^{3} / \mathrm{s}\right)$, while the maximum relative increase was $59 \%$.

Table 6 and Figure 7 show the projected 30-year average water balance factors for the baseline climatology and the eight future climate projections. All the climate projections show an increase in precipitation. Average annual runoff volumes also increased for all the model runs, with increases ranging from just over $1 \%$ for the CGCM2 B2 2050s scenario to $38 \%$ for the HadCM3 A2 2080s scenario. Even higher increases in runoff volume were projected for individual years; the maximum was $47 \%$ in the HadCM3 A2 2080s projection. All model runs also show an increase in evaporation, which is expected because of the increased precipitation and air temperatures. The 30 -year average annual increases range from $10 \%$ for the HadCM3 B2 2050s run to 25\% for the HadCM3 A2 2080s run (Fig. 7). The maximum increase in projected evaporation for individual years is 48\% in the HadCM3 A2 2080s run. Figure 7 also illustrates an important difference in basin response between the two GCMs used. The warm, dry CGCM2 scenarios result in large evaporation increases, but only minor runoff volume increases. The cool, wet HadCM3 scenarios, on the other hand, lead to considerably higher runoff volume changes compared to the changes in amount of evaporation.

Another concern of ecological and hydrological significance for Arctic regions is the impact of changing climatic conditions on the crucial summer runoff volumes from Arctic basins. Figure 8 shows the changes in runoff volumes for summer (defined as July to September) using all eight future climate projections compared to the 1960-91 normal $(44 \mathrm{~mm})$. The model predicts a higher summer runoff volume for six of the eight climate scenarios, indicating that the projected increase in precipitation exceeds the simulated increase in evaporation. This is especially the case for the cool, wet HadCM3 scenarios, which lead to a substantially higher simulated summer runoff volume.

An additional potential consequence of warmer climates in this region is midwinter melt periods that can produce considerable amounts of meltwater and snow cover depletion. For this study, midwinter melts were defined as periods between 1 November and 1 April that produced simulated daily runoff greater than $0.2 \mathrm{~m}^{3} / \mathrm{s}$ for more than five consecutive days in TVC. This threshold 

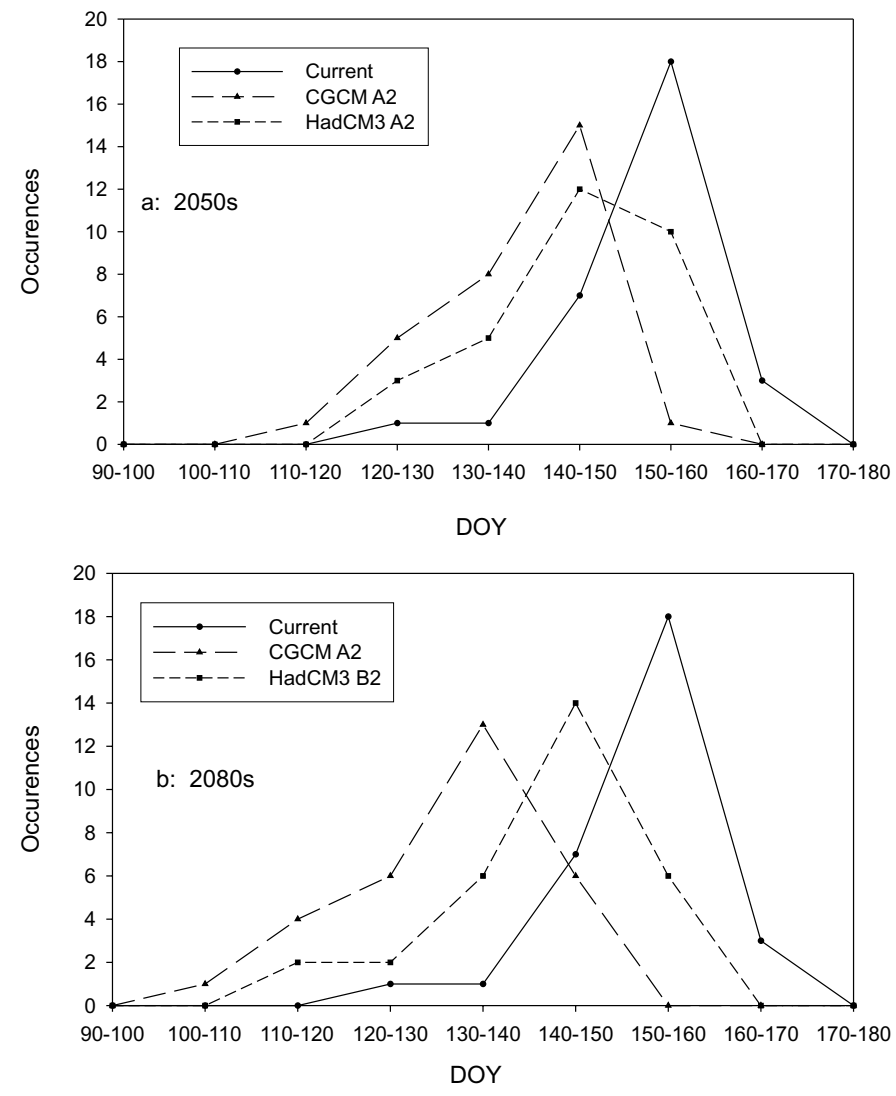

FIG. 6. Number of occurrences of simulated peak runoff dates within 10-day intervals, predicted using two future climate scenarios for (a) the 2050s and (b) the 2080s, compared to the 1960-91 baseline period.

was chosen to ensure that the identified midwinter melt would produce enough meltwater to alter the snowpack properties substantially. None of these events were simulated for the baseline climatology from 1961 to 1990. However, WATFLOOD predicted for the 2050s that between four (CGCM2 B2 and HadCM3 B2) and 10 (CGCM2 A2) of the 30 years had such periods. For the 2080s, WATFLOOD predicted that, for the CGCM2 A2 and HadCM3 A2 scenarios, the majority of the modeled years (16) would experience midwinter melts. The cooler scenarios still produced 11 years (CGCM2 B2) and 7 years (HadCM3 B2) with midwinter melts for the 2080s.

Several naturally occurring processes not specifically addressed in WATFLOOD reduce the likelihood that midwinter melt periods will produce runoff at the TVC basin outlet. For example, meltwater generated at the top of a snow cover must percolate vertically through the snow cover and infiltrate the soil to saturation before it can move laterally to the stream channel. Studies have shown that much of the initial meltwater refreezes in the cold snow cover during percolation or forms basal ice as it reaches the frozen ground (Marsh and Pomeroy, 1996). Should some of the meltwater reach the snow-chocked stream channel, it accumulates and is stored in the snowpack of the stream channel. Runoff is initiated only after a considerable amount of snow in the stream channel melts and enough meltwater accumulates (Kane et al., 1991). The calibrated WATFLOOD
TABLE 6. Water balance and runoff coefficient for baseline climatology and future climate scenarios.

\begin{tabular}{lcccc}
\hline \hline & $\begin{array}{c}\text { Precipitation } \\
\mathrm{mm}\end{array}$ & $\begin{array}{c}\text { Runoff } \\
\mathrm{mm}\end{array}$ & $\begin{array}{c}\text { Evaporation } \\
\mathrm{mm}\end{array}$ & $\begin{array}{c}\text { Runoff } \\
\text { Coefficient }\end{array}$ \\
\hline Baseline Climate & 257 & 166 & 91 & 0.65 \\
CAN A2 2050 & 290 & 179 & 111 & 0.62 \\
CAN B2 2050 & 270 & 167 & 103 & 0.62 \\
HAD A2 2050 & 317 & 211 & 106 & 0.67 \\
HAD B2 2050 & 299 & 198 & 101 & 0.66 \\
CAN A2 2080 & 283 & 170 & 113 & 0.60 \\
CAN B2 2080 & 283 & 172 & 110 & 0.61 \\
HAD A2 2080 & 343 & 228 & 115 & 0.66 \\
HAD B2 2080 & 324 & 215 & 109 & 0.66 \\
\hline \hline
\end{tabular}

model is able to account for these processes during the spring melt, when the snow and the soil are already warmed considerably. However, it is unlikely that WATFLOOD, calibrated for today's spring conditions, can properly account for snowmelt runoff from dry and cold midwinter snow covers. In fact, it is rather unlikely that the projected midwinter melt periods would last long enough and have positive snowmelt energy balances high enough for midwinter runoff to occur. Instead, the produced meltwater would likely refreeze in the snowpack or on the ground. However, the WATFLOOD results clearly show that significant amounts of meltwater are produced during midwinter melt periods under projected future climate conditions. Although such midwinter melt events may not produce streamflow, they would result in the densification of the snowpack and the formation of ice layers within the snow cover and possibly at its base. These changes may have significant negative effects on wildlife such as caribou and moose (Nellemann and Thompson, 1994).

\section{DISCUSSION}

The first objective of this study was to test the performance of the distributed hydrological model WATFLOOD in a small Arctic basin underlain by continuous permafrost. The application of WATFLOOD to TVC for seven years showed that while the model tended to overestimate runoff volumes slightly, the timing of the meltwater runoff was predicted accurately in all model years. This is a very encouraging result, considering that WATFLOOD was developed for more temperate regions and does not expressly include many of the processes crucial for permafrost hydrology. The effective parameters used in the model to simulate the transport of the meltwater from its origin at the top of the snow cover to the basin outlet appear to work adequately for northern basins. Additionally, the study shows that the simple air temperature index algorithm used by WATFLOOD to simulate the snowmelt energy balance, together with the calibrated soil and channel parameters, produces a reasonable meltwater hydrograph. A more detailed modeling of snowpack removal can be achieved with models simulating all terms of 


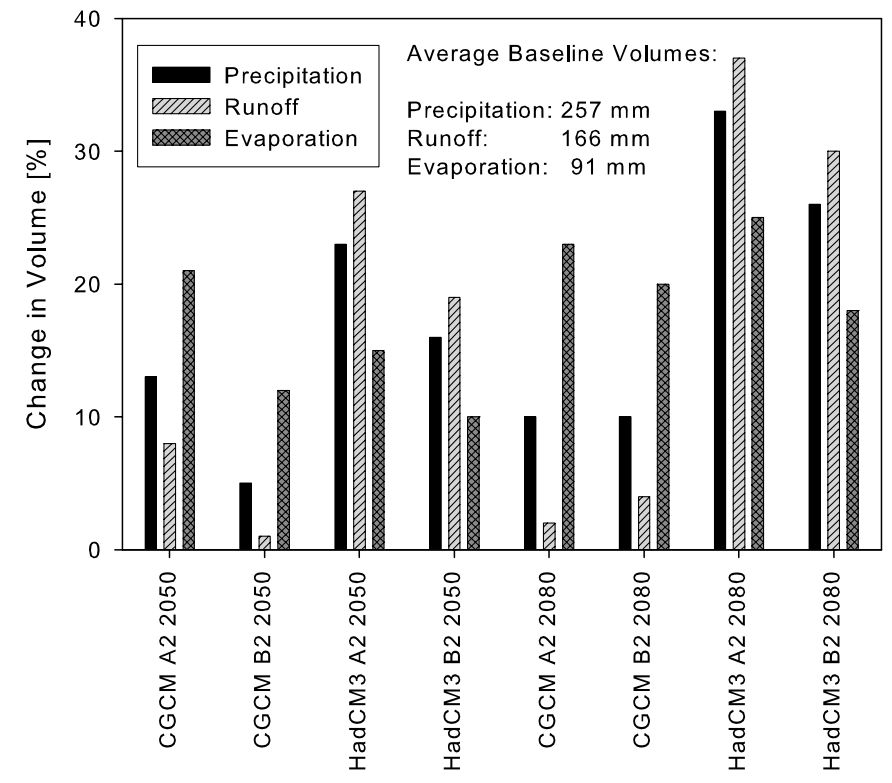

Model Scenarios

FIG. 7. Thirty-year averages in water balance factors for future climate scenarios compared to the 1960-91 baseline climatology.

the snowmelt energy balance (Marks et al., 1999; Woo and Young, 2004; Pohl et al., 2005; Pohl and Marsh, 2006). However, the demands for computation and forcing data are much greater for these models.

The comparison of simulated versus observed runoff hydrographs at the TVC stream gauge when using Inuvik climate data for 17 years of record showed that while model accuracy decreased slightly compared to the model runs using TVC data, the model still produced fairly accurate hydrographs. Especially the crucial timing and amount of spring peak runoff was well predicted by WATFLOOD, indicating that this model could be used to extend runoff records or to generate runoff hydrographs in ungauged basins, provided their hydrological conditions (especially soil and vegetation conditions) are similar to those of other basins for which the model can be calibrated. This is particularly important for Arctic areas, which tend to have a paucity of stream gauges. The accuracy of model predictions is especially satisfactory given that no snow survey results were input into the model.

This study shows that projected warmer spring temperatures have a considerable effect on the timing of the spring snowmelt floods. Dates of first runoff and peak runoff were predicted to be much earlier. Model predictions also suggest a shift in dates of stream freeze-up, with last runoff in many years occurring in late October or early November (rather than late September or early October, as is currently observed). This suggests that the snow-free period will be substantially longer under future climate conditions, with large impacts on plant and animal life, as well as on human infrastructure such as ice roads (Walker et al., 1993; Instanes et al., 2005). The simulations using the future climate scenarios indicate considerably higher

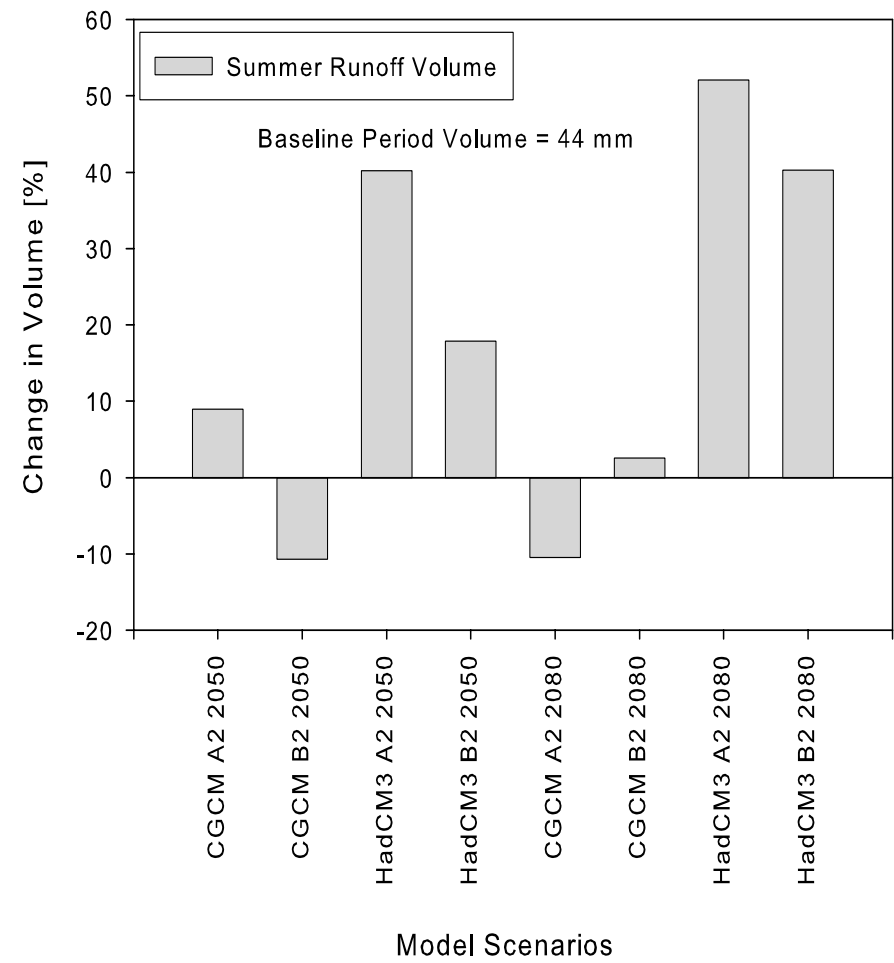

FIG. 8. Summer (July to September) runoff volume for future climate scenarios compared to baseline climatology

overall runoff volumes due primarily to the projected precipitation increase. Runoff volume increases of up to $47 \%$ for individual years were predicted by the model. Such increases will likely have a considerable impact on human settlements (many of which are located along major rivers), roads, and pipelines, as well as on animal migration routes. The model simulations also show a great increase in the number of midwinter melt periods for Arctic regions similar in climate to our study area. Most of the produced meltwater will likely refreeze as ice layers in the snow cover, along the ground, or in the channel snowpack. The resulting changes in snowpack properties include a decreased snow depth, a higher snow density, and a considerable ground ice layer. These changes will greatly affect plant and animal life above and beneath the snow cover (Vörösmarty et al., 2001).

Because of model limitations, several unknown factors influencing the impact of climatic change in the Arctic are not included in this study's simulations. For example, studies on the effects of warmer temperatures on the Arctic suggest that shrub tundra areas will extend northward in response to longer growth periods, and this extension in turn will further affect future snow accumulation and ablation patterns (Liston et al., 2002). Furthermore, the shorter snow-covered periods, coupled with increased air temperatures, are forecast to lead to an increase in the active layer depth in areas of continuous permafrost (Hinzman et al., 1998; Nelson et al., 1998). Both of these processes are likely to lead to further, second-order changes in the spring melt runoff from small Arctic headwater basins. It is expected that these second-order changes will 
not significantly change the results reported here. For example, increased shrub coverage will lead to increased snow storage with a more even distribution across the basin and will likely result in a slightly earlier melt. A deeper active layer will result in more basin storage and will lead to a less "peaky" response to rainfall, but will likely have little impact on overall runoff volume. It can be expected, therefore, that these changes will enhance the trend towards earlier runoff and have little impact on seasonal runoff volume. Future improvements and validation of a full suite of GCM outputs are required before these processes can be considered.

Another unknown factor affecting our predictions of future runoff is the uncertainty of the GCM projections. As is evident from Figure 2, current GCM outputs show a considerable range of projected future temperatures and precipitation amounts. As GCMs evolve over time, this spread in the projections will likely decrease, and hydrological model predictions of the impact of future climate on streamflow should become more certain.

\section{CONCLUSIONS}

The study showed that the distributed hydrological model WATFLOOD can accurately predict the runoff hydrographs from a small Arctic headwater basin (Trail Valley Creek) located just east of the Mackenzie Delta. Model performance decreased slightly when using climate data observed more than $50 \mathrm{~km}$ away at Inuvik. However, model predictions showed reasonable agreement between modeled and observed runoff, especially in runoff timing. WATFLOOD was subsequently used to study the effects of projected climate changes on runoff from small Arctic basins. The simulation showed a considerable shift in the 30-year average dates of first and peak runoff. Annual runoff volumes were consistently predicted to be higher, although spring peak flow values did not change much. The simulations for future climates also showed a large number of midwinter melt periods for the study area (up to 16 out of the 30 years were affected). Overall, the projected shorter snow-covered periods, earlier spring runoffs, and changing snow cover conditions will have major impacts on human, animal, and plant life. Although this study considered only first-order impacts, it is not expected that the second-order changes will greatly affect the trends towards midwinter melt, earlier runoff, and higher annual discharge.

\section{REFERENCES}

ACIA (ARCTIC CLIMATE IMPACT ASSESSMENT). 2004. Impacts of a warming Arctic: Arctic climate impact assessment. Cambridge: Cambridge University Press. 140 p.

BONSAL, B.R., and PROWSE, T.D. 2003. Trends and variability in spring and autumn $0^{\circ} \mathrm{C}$ isotherm dates over Canada. Climate Change 57:341-358.
DAVISON, B., POHL, S., DORNES, P., MARSH, P., and PIETRONIRO, A. 2006. Modelling snowmelt variability in the land-surface-hydrologic model WATCLASS. AtmosphereOcean 44:271-287.

DONALD, J.R., SOULIS, E.D., KOUWEN, N., and PIETRONIRO, A. 1995. A land cover-based snow cover representation for distributed hydrologic models. Water Resources Research 31:995-1009.

DORNES, P., PIETRONIRO, A., TOTH, B., and TÖYRA, J. 2004. Future climate change scenarios for the Mackenzie River basin. In: Proceedings of the 10th Annual Scientific Meeting of the Mackenzie GEWEX Study (MAGS), 3-5 November, Vancouver, British Columbia. 112-130.

ENVIRONMENT CANADA. 2002. Canadian climate normals 1971-2000. Downsview, Ontario: Atmospheric Environment Service. http://www.climate.weatheroffice.ec.gc.ca/climate _normals/index_e.html.

ESSERY, R., LONG, L., and POMEROY, J.W. 1999. A distributed model of blowing snow over complex terrain. Hydrological Processes 13:2423-2438.

EVANS, B.M., WALKER, D.A., BENSON, C.S., NORDSTRAND, E.A., and PETERSEN, C.W. 1989. Spatial interrelationships between terrain, snow distribution and vegetational patterns at an Arctic foothills site in Alaska. Holarctic Ecology 12: $270-278$

GERLAND, S., WINTHER, J.G., ORBAEK, J.B., LISTON, G.E., ORELAND, N.A., BLANCO, A., and IVANOV, B. 1999. Physical and optical properties of snow covering Arctic tundra on Svalbard. Hydrological Processes 13:2331-2343.

HINZMAN, L.D., and KANE, D.L. 1991. Snow hydrology of a headwater Arctic basin. 2. Conceptual analysis and computer modeling. Water Resources Research 27:1111-1121.

HINZMAN, L.D., GORING, D.J., and KANE, D.L. 1998. A distributed thermal model for calculating soil temperature profiles and depth of thaw in permafrost regions. Journal of Geophysical Research 103:975-991.

INSTANES, A., ANISIMOV, O., BRIGHAM, L., GOERING, D., KHRUSTALEV, L.N., LADANYI, B., and LARSEN, J.O. 2005. Infrastructure: Buildings, support systems, and industrial facilities. In: Arctic climate impact assessment. Cambridge: Cambridge University Press. 908-944.

IPCC (INTERGOVERNMENTAL PANEL ON CLIMATE CHANGE). 2001. Climate change 2001: Synthesis report. A Contribution of Working Groups I, II, and III to the Third Assessment Report of the IPCC. Watson, R.T., and the Core Writing Team, eds. Cambridge: Cambridge University Press. $398 \mathrm{p}$.

KANE, D.L., HINZMAN, L.D., BENSON, C.S., and LISTON, G.E. 1991. Snow hydrology of a headwater Arctic basin. 1. Physical measurements and process studies. Water Resources Research 27:1099-1109.

KATTSOV, V.M., KÄLLÉN, E., CATTLE, H., CHRISTENSEN, J., DRANGE, H., HANSSEN-BAUER, I., JÓHANNESEN, T., KAROL, I., RÄISÄNEN, J., SVENSSON, G., and VAVULIN, S. 2005. Future climate change: Modeling and scenarios for the Arctic. In: Arctic climate impact assessment. Cambridge: Cambridge University Press. 100-146. 
KOUWEN, N. 2001. WATFLOOD/SPL9 hydrological model \& flood forecasting system since 1972: User's manual. Waterloo, Ontario: University of Waterloo. 192 p.

KOUWEN, N., and MOUSAVI, S.F. 2002. WATFLOOD/SPL9 hydrological model \& flood forecasting system. In: Singh, V.P., and Frevert, D.K., eds. Mathematical models of large watershed hydrology. Highlands Ranch, Colorado: Water Resources Publications, LLC. 649-685.

KOUWEN, N., SOULIS, E.D., PIETRONIRO, A., DONALD, J., and HARRINGTON, R.A. 1993. Grouped response units for distributed hydrologic modeling. Journal of Water Resources Planning and Management 119:289-305.

LISTON, G.E., McFADDEN, J.P., STURM, M., and PIELKE, R.A., Sr. 2002. Modelled changes in Arctic tundra snow, energy and moisture fluxes due to increased shrubs. Global Change Biology 8:17-32.

LOENG, H., BRANDER, K., CARMACK, E., DENISENKO, S., DRINKWATER, K., HANSEN, B., KOVACS, K., LIVINGSTON, P., McLAUGHLIN, F., and SAKSHAUG, E. 2005. Marine systems. In: Arctic climate impact assessment. Cambridge: Cambridge University Press. 454-524.

MALE, D.H., and GRANGER, R.J. 1981. Snow surface energy exchange. Water Resources Research 17:609-627.

MARKS, D., DOMINGO, J., SUSONG, D., LINK, T., and GAREN, D. 1999. A spatially distributed energy balance snowmelt model for application in mountain basins. Hydrological Processes 13:1935-1959.

MARSH, P. 1999. Snowcover formation and melt: Recent advances and future prospects. Hydrological Processes 13:2117-2134.

MARSH, P., and POMEROY, J.W. 1996. Meltwater fluxes at an Arctic forest-tundra site. Hydrological Processes 10: $1383-1400$.

MARSH, P., and WOO, M.K. 1981. Snowmelt, glacier melt, and high Arctic streamflow regimes. Canadian Journal of Earth Sciences 18:1380-1384.

MARSH, P., ONCLIN, C., and NEUMANN, N.N. 2002. Water and energy fluxes in the lower Mackenzie valley. AtmosphereOcean 40:245-256.

MARSH, P., ONCLIN, C., RUSSELL, M., and POHL, S. 2003. Effects of shrubs on snow processes in the vicinity of the Arctic treeline in NW Canada. In: Proceedings of the Northern Research Basins 14th International Symposium and Workshop, 25-29 August 2003, Kangerlussuaq/Søndre Strømfjord, Greenland. $113-118$.

McNAMARA, J.P., KANE, D.L., and HINZMAN, L.D. 1998. An analysis of streamflow hydrology in the Kuparuk River Basin, Arctic Alaska: A nested watershed approach. Journal of Hydrology 206:39-57.

NAKICENOVIC, N., ALCAMO, J., DAVIS, G., de VRIES, B., FENHANN, J., GAFFIN, S., GREGORY, K., GRÜBLER, A., JUNG, T., KRAM, T., LA ROVERE, E., MICHAELIS, L., MORI, S., MORITA, T., PEPPER, W., PITCHER, H., PRICE, L., RIAHI, K., ROEHRL, A., ROGNER, H.H., SANKOVSKI, A., SCHLESINGER, M., SHUKLA, P., SMITH, S., SWART, R., VAN ROOIJEN, S., VICTOR, N., and DADI, Z. 2000. Special report on emissions scenarios. Cambridge: Cambridge University Press. 599 p.
NELLEMANN, C., and THOMSEN, M.G. 1994. Terrain ruggedness and caribou forage availability during snowmelt on the Arctic Coastal Plain, Alaska. Arctic 47(4):361-367.

NELSON, F.E., HINKEL, K.M., SHIKLOMANOV, N.J., MUELLER, G.R., MILLER, L.L., and WALKER, D.K. 1998. Active-layer thickness in north central Alaska: Systematic sampling, scale, and spatial autocorrelation. Journal of Geophysical Research 103:963-973.

PETRONE, R.M., ROUSE, W.R., and MARSH, P. 2000. Comparative surface energy budgets in western and central subarctic regions of Canada. International Journal of Climatology 20:1131-1148.

PIETRONIRO, A., PROWSE, T., HAMLIN, L., KOUWEN, N., and SOULIS, E. 1996. Application of a grouped response unit hydrological model to a northern wetland region. Hydrological Processes 10:1245-1261.

POHL, S., and MARSH, P. 2006. Small-scale modelling of spatially variable snowmelt in an Arctic catchment. Hydrological Processes 20:1773-1792.

POHL, S., DAVISON, B., MARSH, P., and PIETRONIRO, A. 2005. Modelling spatially distributed snowmelt and meltwater runoff in a small Arctic catchment with a hydrology-land surface scheme (WATCLASS). Atmosphere-Ocean 43:193-211.

POHL, S., MARSH, P., and LISTON, G.E. 2006. Spatial-temporal variability in turbulent fluxes during spring snowmelt. Arctic, Antarctic, and Alpine Research 38:136-146.

POMEROY,J.W., MARSH, P., and GRAY,D.M. 1997. Application of a distributed blowing snow model to the Arctic. Hydrological Processes 11:1451-1464.

QUINTON, W.L., and MARSH, P. 1999. A conceptual framework for runoff generation in a permafrost environment. Hydrological Processes 13:2563-2581.

RANGO, A. 1992. Worldwide testing of the snowmelt runoff model with applications for predicting the effects of climate change. Nordic Hydrology 23:155-172.

RANGO, A., and MARTINEC, J. 1995. Revisiting the degree-day method for snowmelt calculations. Water Resources Bulletin 31:657-669.

ROSENZWEIG, D., and PARRY, M.L. 1994. Potential impact of climate change on world food supply. Nature 367:133-138.

SNELGROVE, K.R. 2002. Implications of lateral flow generation on land-surface scheme fluxes. PhD Thesis, University of Waterloo, Ontario.

SOULIS, E.D., SNELGROVE, K.R., KOUWEN, N., SEGLENIEKS, F., and VERSEGHY, D.L. 2000. Towards closing the vertical water balance in Canadian atmospheric models: Coupling of the land surface scheme CLASS with the distributed hydrological model WATFLOOD. AtmosphereOcean 38(1):251-269.

TRANTER, M., and JONES, H.G. 2001. The chemistry of snow: Processes and nutrient cycling. In: Jones, H.G., Pomeroy, J.W., Walker, D.A., and Hoham, R.W., eds. Snow ecology: An interdisciplinary examination of snow-covered ecosystems. Cambridge: Cambridge University Press. 127-168.

VINCENT, L.A. 1998. A technique for the identification of inhomogeneities in Canadian temperature series. Journal of Climate 11:1094-1104. 
VINCENT, L.A., and GULLETT, D.W. 1999. Canadian historical and homogeneous temperature datasets for climate change analysis. International Journal of Climatology 19:1375-1388.

VINCENT, L.A., ZHANG, X., BONSAL, B.R., and HOGG, W.D. 2002. Homogenization of daily temperatures over Canada. Journal of Climate 15:1322-1334.

VÖRÖSMARTY, C.J., HINZMAN, L.D., PETERSON, B.J., BROMWICH, D.H., HAMILTON, L.C., MORISON, J., ROMANOVSKY, V.E., STURM, M., and WEBB, R.S. 2001. The hydrologic cycle and its role in Arctic and global environmental change: A rationale and strategy for synthesis study. Fairbanks, Alaska: Arctic Research Consortium of the United States. 84 p.
WALKER, D.A., HALFPENNY, J.C., WALKER, M.D., and WESSMANN, C.A. 1993. Long-term studies of snow-vegetation interactions. Bioscience 43:287-301.

WALKER, M.D., WALKER, D.A., WELKER, J.M., ARFT, A.M., BARDSLEY, T., BROOKS, P.D., FAHNESTOCK, J.T., JONES, M.H., LOSLEBEN, M., PARSONS, A.N., SEASTEDT, T.R., and TURNER, P.L. 1999. Long-term experimental manipulation of winter snow regime and summer temperature in Arctic and alpine tundra. Hydrological Processes 13:2315-2330.

WOO, M.K., and YOUNG, K.L. 2004. Modelling Arctic snow distribution and melt at the 1- km grid scale. Nordic Hydrology 35:295-307.

ZHANG, X., VINCENT, L.A., HOGG, W.D., and NIITSOO, A. 2000. Temperature and precipitation trends in Canada during the 20th century. Atmosphere-Ocean 38:395-429. 